\title{
优化班级管理，践行道德教育 初中班主任德育工作思考
}

杜佶真

广西省南宁市第二中学

DOI:10.32629/jief.v2i6.1118

[摘要] 随着新课改工作的深入推进, 学校和教师的教育理念也发生较大变化, 开始重视起德育工作。班主任开展班级管理过程中, 应积极 践行德育教育，以德立教、立德树人。本文将探讨初中德育工作的重要性，并提出具体实施策略，旨在为广大学校和班主任提供参考。

[关键词] 初中; 德育工作; 班级管理; 班主任

中图分类号: G633.2 文献标识码: A

进入初中, 学生面临的环境以及自身心理会出现较大变化。与小学 阶段不同, 初中生往往会出现较大的思想波动。因此, 学校和班主任应 该重视起这种变化, 并保证德育工作可以顺利实施, 使学生具有较高的 思想道德水平以及正确的三观, 进而健康快乐的成长。

\section{1 初中班主任德育工作开展的重要性}

传统教育相对于素质教育来说, 存在较多缺陷, 无法满足新课改的 要求。以往教育过程中, 班主任与学生缺乏沟通, 无法了解每位学生的 细微心理变化, 不能满足学生的心理需求。而这一阶段的学生思想正在 成熟, 会受到不同思想的影响, 甚至被不良思想带入歧途。因此, 需要 班主任重视起学生心理变化, 及时开展德育教育工作, 保证学生在这一 阶段的成长过程中形成正确的三观。

\section{2 初中班主任德育工作开展的有效策略}

\section{1 提高班主任德育修养}

古往今来, 言传身教是每一位教育工作者追求的方式, 班主任也应 从自身做起, 这样才有利于班级德育工作的开展。班主任要有积极向上 的思想、正确的道德理念, 并使自己的文化素养能够达到较高的程度。 这样，在德育工作中才可以激励学生、教育学生、引导学生。

因此, 班主任要不断学习德育知识, 使自身的理论基础有所提高, 从而更好地开展德育工作。对于学生的心理辅导方面, 要求班主任研究 相关的心理学知识, 从而使学生的身心健康得到保障。在学校中, 班主 任与学生的接触时间较长, 其思想观念和行为方式等都会在较大程度上 影响到学生。这就需要班主任规范自身行为举止, 与学生交流时做到文 明得体, 做好自身的表率工作。这样以后开展德育工作时, 班主任才能 够有方向、有依据、有底气。

2.2 创新德育工作的方式

传统教学中, 班主任进行德育教育仅有思想道德教育, 这种德育工 作方式比较死板, 不符合新时代下的教学要求。因此, 班主任需要对德 育工作的方式进行创新, 使用多元化的方法紧抓学生心理, 进而不断提 升德育工作的效果。除此之外, 班主任开展德育工作的过程中, 应该结 合实际来丰富教学内容, 使学生学到较多的德育理论。班主任安排德育 教育课时, 应该具备科学性, 防止一些学生对德育课产生厌恶。班主任 要能够结合实际情况, 不断创新德育工作方式, 从而帮助学生形成正确 的道德观念和人生价值观。

2.3 做好德育实践教育

德育教育与文化知识教育一样, 单纯纸上谈兵无法起到应有的效果。 因此, 班主任要有效结合生活实践和德育教育, 将德育工作落实到实处。 班主任可利用各种班级活动来渗透德育教育, 包括学习活动以及相关的 社会实践活动等, 从而提高德育工作的效果。比如, 培养学生竞争意识 和责任意识的过程中, 班主任可以提出小组合作的方式, 引导学生在小
组间互相竞争、小组内互相帮助。这种形式能够让学生认识到自身对小 组的影响, 树立学生的责任感。同时, 友好的竞争环境有利于学生竞争 意识的树立, 对其未来发展有较大的作用。具体的实践活动需要教师根 据实际情况来安排, 比如为培养学生尊老爱幼、帮助他人、乐善好施等 优秀品质, 可以组织学生去敬老院进行慰问, 通过帮助老人的方式来提 升学生的德育水平。

\section{4 公平对待每一位学生}

作为班主任, 首先应该明确了解 “人人生而平等”。每一位学生在 班主任眼中都应是平等的, 即使因为家庭背景、性格、成绩等存在区别, 但应受到班主任的平等对待。因此, 班主任在工作过程中, 不要随意根 据成绩为学生划分等级, 避免一些学生产生自卑心理。只有班主任在工 作中真正做到对所有学生一视同仁，不偏向成绩良好的学生、不解急成 绩较差的学生, 才能够让学生养成平等待人、尊重差异等优良的品质。

班级德育工作开展过程中，班主任首先应树立起平等待人的思想， 对于学生出现的个体差异给予充分尊重, 保证每位学生都能够被公平公 正对待。其次, 班主任应该针对不同的学生开展不同的教育, 以平等的 态度来对待学生的个体化差异, 进而发现不同学生的优点。只有根据学 生的不同情况, 班主任才能够用不同的方式来教育学生、引导学生, 从 而使每位学生都能够得到全面发展, 进而在以后的工作生活中充分发挥 自身的价值。例如, 对于学习成绩排在较后的学生, 班主任不应责备, 而应在与学生的沟通交流中发现学生的优点。如果学生擅长音乐、舞蹈、 体育等, 那么班主任就应进行鼓励、引导, 帮助学生来发挥自身特长, 保证每位学生都能够获得良好发展。实际工作中, 班主任要充分学习相 关心理学知识, 使自己的思想能够与学生的思想融成一片。班主任可以 利用学生的课余时间来组织学生开展活动, 进入到学生中间, 以此来了 解学生的德育养成情况和内心想法。然后根据学生的实际情况对德育工 作方式进行改进，进而提升德育工作的效果。

\section{3 结束语}

初中阶段对学生来说是特别重要的, 这个时期的学生思想还不够成 熟, 需要在班主任的帮助下形成正确的人生价值观。班级管理工作中, 班主任要重视起德育教育, 并不断创新德育教育的方式、不断提高自身 专业素养, 从而保证每一位学生都能够得到健康发展。

\section{[参考文献]}

[1]韩丽萍. 提升初中班主任德育能力的实践研究 [J]. 新课 程,2020(37):223.

[2]马国彦.初中班主任基于微信开展互动德育探索[J].新课 程,2020(37):224.

[3]王和.新时期初中班主任德育工作策略 [J]. 文学教育 (下),2020(08):174-175. 